https://doi.org/10.15407/mineraljournal.43.03.085

UDC 551.734.3+4+552.513

L.V. Shumlyanskyy, DrSc (Geology), Senior Research Fellow, Leading Researcher

M.P. Semenenko Institute of Geochemistry, Mineralogy

and Ore Formation of the NAS of Ukraine

34, Acad. Palladin Ave., Kyiv, Ukraine, 03142

E-mail: lshumlyanskyy@yahoo.com; http:/ / orcid.org/0000-0002-6775-4419

M. Hofmann, PhD (Geology), Head of the Lab.

Senckenberg Naturhistorische Sammlungen, Dresden, Germany

E-mail: mandy.hofmann@senckenberg.de; ScopusID: 35334126200

B.V. Borodynya, Head of a party

State Enterprise "Pivdenukrgeologiya"

11, Chernyshevskoho Str., Dnipro, Ukraine, 49005

E-mail: boris.priazov@gmail.com

G.V. Artemenko, DrSc (Geology), Prof. Head of Department

M.P. Semenenko Institute of Geochemistry, Mineralogy

and Ore Formation of the NAS of Ukraine

34, Acad. Palladin Ave., Kyiv, Ukraine, 03142

E-mail: regulgeo@gmail.com; https:/ / orcid.org/0000-0002-4528-6853

\title{
THE LOCAL SOURCES OF DETRITAL MATERIAL IN MIDDLE DEVONIAN QUARTZITES OF THE DONETS BASIN: RESULTS OF U-Pb LA-ICP-MS ZIRCON DATING
}

Results of $U$-Pb dating of zircons from the Middle Devonian sandstones of the Mykolaivka Suite, taken from the junction zone between the Azov Domain of the Ukrainian Shield and Donets basin, are reported. The rocks are taken from a drill core and they occur beneath a $210 \mathrm{~m}$ sequence of mafic and ultramafic volcanic rocks that belong to the Antonivka $\left(D_{2-3}\right)$ and Mykolaivka ( $\left.D_{2}\right)$ suites. In total, $28 \mathrm{U}$-Pb isotope analyses were performed. The predominant population (18 grains) of zircons yielded a concordant age of $2075 \pm 9 \mathrm{Ma}(\mathrm{MSWD}=0.64)$. The second largest population consists of zircon crystals with concordant to nearly concordant ages ranging from 3130 to $2830 \mathrm{Ma}$. These results indicate a local origin for the detrital zircons. The occurrence of coarse-grained terrigenous sediments, derived from local rock sources, indicates significant erosion of the Precambrian basement that might have been caused by differential vertical movements during the Middle Devonian period. In the Donets basin, rifting and uplift started ca. 10 Myr before that of other parts of the Prypyat-Dnieper-Donets Paleorift.

Keywords: Donets basin, detrital zircon, $U-P b$ age, Devonian.

Introduction. The $\mathrm{U}-\mathrm{Pb}$ dating of detrital zircons and other minerals (monazite, rutile, apatite), often accompanied by a determination of $\mathrm{Hf}$ and $\mathrm{O}$ isotope systematics and trace element composition, is a powerful tool for investigation the clastic rocks, i.e. their age and provenance, and for deciphering of the tectonic setting of their deposition $[5,8,9,11]$. The rapid outspread of the research facilities that allow fast, cheap, and reliable in-situ dating of small volumes of material has resulted in a dramatic increase in the number of publications focused on detrital studies. Numerous research works have been published recently regarding the $\mathrm{U}-\mathrm{Pb}$ dating of detrital zircons (and other minerals) in sedimentary formations of Ukraine. Most of them were focused on the Precambrian formations

Cite: Shumlyanskyy, L.V., Hofmann, M., Borodynya, B.V. and Artemenko, G.V. (2021), The Local Sources of Detrital Material in Middle Devonian Quartzites of the Donets Basin: Results of U-Pb LA-ICP-MS Zircon Dating, Mineral. Journ. (Ukraine), Vol. 43, No. 3, pp. 85-90. https://doi.org/10.15407/mineraljournal.43.03.085 


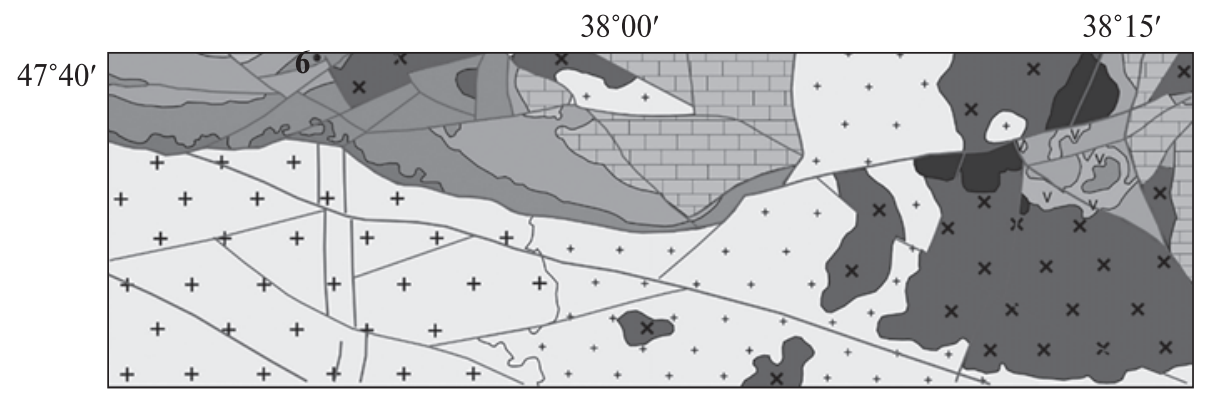

$\square 1 \square 2 \square \mathrm{v} 3 \square 4 \square 5 \square 6+7 \square 8 \mathrm{x} 9 \bullet 10 \quad 4 \mathrm{~km}$
Fig. 1. Simplified geological map of the junction zone of the Donets basin and Azov Domain of the Ukrainian Shield: 1-6 - Palaeozoic (1 - Early Carboniferous, predominantly carbonate rocks; 2 - Late Devonian, predominantly terrigenous rocks with tuffite admixture;
volcanic rocks; 5 - Middle3 - Late Devonian syenite and nepheline syenite; 4- Middle-late Devonian, mafic-ultramafic volcanic rocks; 5- Middle-
late Devonian pyroxenites and ultramafic-alkaline rocks; 6 - Middle Devonian, mafic-ultramafic volcanic rocks with interlayers of terrigenous and carbonate rock); 7, 8- Paleoproterozoic ( 7 - Khlibodarivka complex (ca. 2040 Ma): granite, granosyenite, syenite, quartz monzonite; 8-Anadol complex (ca. $2080 \mathrm{Ma}$ ): granite and migmatite); 9 - Archean: Maksymivka granodiorite association; 10 - location of drill hole \#6

Fig. 2. Optical ( $a$ ) and CL $(b)$ images of zircons separated from sandstone of the Mykolaivka Suite, sample $6 / 227.5$

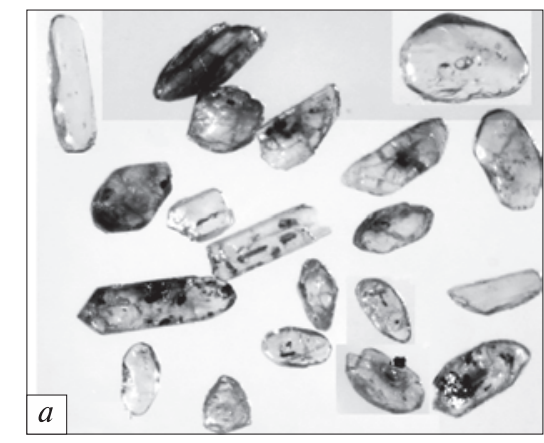

[e.g., 1-4, 10, 16, 22-24], and only a few were dedicated to the Phanerozoic sedimentary sequences [15, 21].

In this study, we report results of $\mathrm{U}-\mathrm{Pb}$ dating of zircons from Middle Devonian sandstones that were sampled in the junction zone between the Azov Domain of the Ukrainian Shield and Donets basin which represents a part of the Paleozoic Prypyat-Dnieper-Donets paleorift. We aimed at the determination of the provenance of the detrital material and establishing the tectonic setting of their deposition.

Geological setting and sample description. The Prypyat-Dnieper-Donets paleorift (PDDP) occurs in the south-western part of the East European platform, where it is bounded by the Ukrainian shield to the south and Voronizh Crystalline Massif to the north. The paleorift consists of three segments - the Prypyat basin, Dnieper basin and Donets basin. The formation of the paleorift was linked to the mantle plume formation during the Late Frasnian (ca. 375-372 Ma), whereas the regional uplift may have commenced already in the mid-Frasnian (ca. $378 \mathrm{Ma}$ ) [25]. The main extensional phase in the Dnieper-Donets part of the PDDP occurred between the late Frasnian (372 Ma)

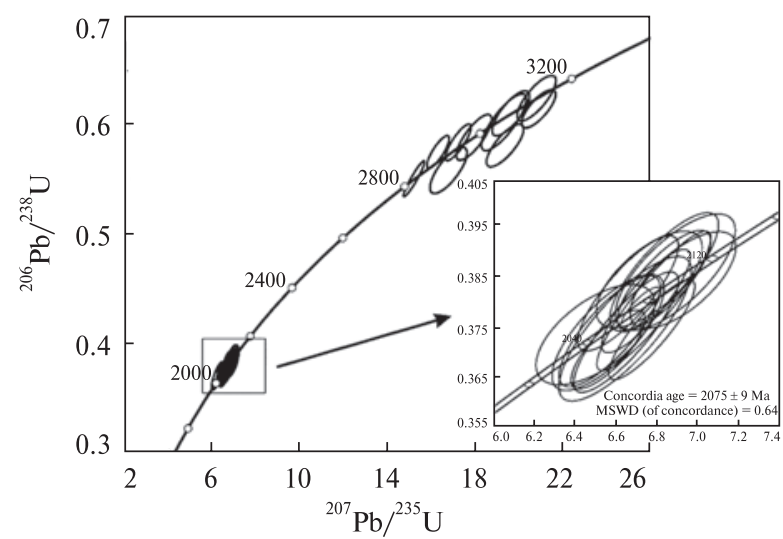

Fig. 3. U-Pb diagram with results of zircon dating

and the end of the Devonian (363 Ma) [13]. The formation of the PDDP was accompanied by extensive mafic-ultramafic magmatism that affected not only the PDDP itself but also surrounding areas [12, 17, 20, 25, 27].

The age of sedimentary sequences is constrained paleontologically, whereas the age of the Devonian volcanic rocks remains poorly known due to a lack of suitable mineral geochronometers. Numerous $\mathrm{K}-\mathrm{Ar}$ and ${ }^{40} \mathrm{Ar} /{ }^{39} \mathrm{Ar}$ ages obtained for these rocks 
are quite variable and indicative of Ar loss or resetting of the K-Ar isotope system. A remarkable exclusion is the age of kimberlite pipes that occur in the junction zone between the Azov Domain and Donets basin. Four kimberlite pipes are known in this area, two of which were dated at $384.7 \pm 3.9$ and $383.3 \pm 3.8 \mathrm{Ma}$ (Pivdenna and Novolaspa pipes, respectively) applying the $\mathrm{Rb}-\mathrm{Sr}$ isochron method on phlogopite and whole-rock samples [26]. Three of these intrusions cut Paleoproterozoic granitoids whereas one of them, the Petrivske pipe, cut sedimentary rocks of the Middle Devonian Mykolaivka Suite and covered by volcanites of the Antonivka Suite (Middle-Late Devonian). Noteworthy, kimberlites of the Pivdenna pipe contain xenoliths of limestones, sandstones and schists of the Mykolaivka Suite [26]. Hence, the age of kimberlites defines the age of the Mykolaivka Suite as Givetian to Eifelian.
The Mykolaivka Suite comprises two sub-suites, the lower one being composed of gravels, sandstones, limestones, dolomites and schists, and the upper one embracing mafic and ultramafic volcanic rocks (including tuffs), limestones, gravels, sandstones, and schists. Presently, their occurrence is limited to the Donets basin, whereas their presence as xenoliths in kimberlites of the Pivdenna pipe indicates a much wider distribution of the suite in the past. The tectonic setting during the sedimentation of the Mykolaivka Suite was described as a "passive rifting with a shallow marine sedimentation", which consequently changed to a "continental rifting associated with basement uplift, fluviatile sedimentation and subaerial basaltic volcanism" [6].

The studied sample represents the sandstone of the Mykolaivka Suite (Eifelian Stage of the Middle Devonian) that was collected from drill hole 6 at a depth of $227.5 \mathrm{~m}$ (Fig. 1). In the drill hole, these

Results of $\mathrm{U}-\mathrm{Pb} \quad-\quad-M S$ dating of detrital zircons from sandstone of the Mykolaivka Suite, sample 6/227.5

\begin{tabular}{|c|c|c|c|c|c|c|c|c|c|c|c|c|c|c|c|}
\hline \multirow[b]{2}{*}{ \# } & \multicolumn{7}{|c|}{ Isotope ratios } & \multicolumn{6}{|c|}{ Isotope ages, Ma } & \multirow{2}{*}{$\begin{array}{c}\text { Conc., } \\
\%\end{array}$} & \multirow{2}{*}{$\frac{\mathrm{Th}}{\mathrm{U}}$} \\
\hline & $\frac{{ }^{207} \mathrm{~Pb}}{{ }^{235} \mathrm{U}}$ & $2 \sigma, \%$ & $\frac{{ }^{206} \mathrm{~Pb}}{{ }^{238} \mathrm{U}}$ & $2 \sigma, \%$ & Corr & $\frac{{ }^{207} \mathrm{~Pb}}{{ }^{206} \mathrm{~Pb}}$ & $2 \sigma, \%$ & $\frac{{ }^{207} \mathrm{~Pb}}{{ }^{235} \mathrm{U}}$ & $2 \sigma$ & $\frac{{ }^{206} \mathrm{~Pb}}{{ }^{238} \mathrm{U}}$ & $2 \sigma$ & $\frac{{ }^{207} \mathrm{~Pb}}{{ }^{206} \mathrm{~Pb}}$ & $2 \sigma$ & & \\
\hline 1 & 6.6397 & 4.0 & 0.37510 & 3.2 & 0.80 & 0.1284 & 2.4 & 2065 & 36 & 2053 & 57 & 2076 & 42 & 99 & 0.37 \\
\hline 2 & 17.2011 & 2.8 & 0.58453 & 2.3 & 0.84 & 0.2134 & & 2946 & 27 & 2967 & 56 & 2932 & 25 & 101 & 0.17 \\
\hline 3 & 6.5637 & 3.1 & 0.37459 & 2.5 & 0.80 & 0.1271 & 1.9 & 2054 & 28 & 2051 & 43 & 2058 & 33 & 100 & 0.44 \\
\hline 4 & 6.6447 & 3.2 & 0.37442 & 2.7 & 0.85 & 0.1287 & 1.7 & 2065 & 28 & 2050 & 47 & 2080 & 30 & 99 & 0.71 \\
\hline 5 & 15.1941 & 2.6 & 0.55126 & 2.4 & 0.94 & 0.1999 & 0.8 & 2827 & 25 & 2830 & 56 & 2825 & 14 & 100 & 0.36 \\
\hline 6 & 6.7806 & 3.4 & 0.38077 & 3.0 & 0.91 & 0.1292 & 1.4 & 2083 & 30 & 2080 & 54 & 2086 & 25 & 100 & 0.54 \\
\hline 7 & 6.8865 & 3.5 & 0.38666 & 2.5 & 0.72 & 0.1292 & 2.4 & 2097 & 31 & 2107 & 45 & 2087 & 43 & 101 & 1.04 \\
\hline 8 & 6.5567 & 2.3 & 0.37091 & 1.8 & 0.78 & 0.1282 & 1.4 & 2054 & 20 & 2034 & 31 & 2074 & 25 & 98 & 0.59 \\
\hline 9 & 6.5560 & 3.4 & 0.37437 & 2.6 & 0.75 & & 2.3 & 2053 & 31 & 2050 & 4 & 057 & 40 & 100 & 0.45 \\
\hline 10 & 20.8652 & 3.0 & 0.61527 & 2.3 & 0.76 & 0.2460 & 2.0 & 3132 & 30 & 3091 & 5 & 3159 & 31 & 98 & 0.49 \\
\hline 11 & 16.7582 & 4.1 & 0.55891 & 3.1 & 0.76 & 0.2175 & 2.7 & 2921 & 40 & 2862 & 7 & 2962 & 44 & 97 & 0.62 \\
\hline 12 & 6.9237 & 3.1 & 0.38507 & 2.1 & 0.68 & 0.1304 & 2.2 & 2102 & 28 & 2100 & 38 & 2103 & 39 & 100 & 0.75 \\
\hline 13 & 6.4941 & 3.7 & 0.37389 & 2.2 & 0.61 & 0.1260 & 2.9 & 2045 & 33 & 2048 & 35 & 2043 & 52 & 100 & 2.05 \\
\hline 14 & 19.2804 & 4.3 & 0.60303 & 3.5 & 0.81 & 0.2319 & 2.5 & 3056 & 43 & 3042 & 86 & 3065 & 41 & 99 & 0.49 \\
\hline 15 & 19.3378 & 3.6 & 0.58168 & 2.8 & 0.77 & 0.2411 & 2.3 & 3059 & 35 & 2956 & 66 & 3127 & 36 & 95 & 0.33 \\
\hline 16 & 6.7707 & 2.5 & 0.37495 & 2.2 & 0.87 & 0.1310 & & 2082 & 23 & 2053 & & 2111 & 22 & 97 & 0.40 \\
\hline 17 & 6.6545 & 3.0 & 0.38231 & 2.5 & 0.83 & 0.1262 & 1.7 & 2067 & 27 & 2087 & 45 & 2046 & 30 & 102 & 0.35 \\
\hline 18 & 19.5985 & 3.6 & 0.61115 & 2.8 & 0.77 & 0.2326 & 2.3 & 3072 & 35 & 3075 & 68 & 3070 & 36 & 100 & 0.14 \\
\hline 19 & 6.2304 & 3.6 & 0.37030 & 2.8 & 0.79 & & & 2009 & 32 & 2031 & 50 & 1986 & 40 & 102 & 0.35 \\
\hline 20 & 17.9176 & 3.7 & 0.58915 & 2.9 & 0.79 & 0.2206 & 2.2 & 2985 & 36 & 2986 & 70 & 2985 & 36 & 100 & 0.07 \\
\hline 21 & 6.9687 & 2.6 & 0.38201 & 2.2 & 0.82 & 0.1323 & 1.5 & 2107 & 24 & 2086 & 38 & 2129 & 27 & 98 & 0.45 \\
\hline 22 & 6.9346 & 2.7 & 0.37946 & 2.1 & 0.79 & 0.1325 & 1.7 & 2103 & 24 & 2074 & 38 & 2132 & 29 & 97 & 0.55 \\
\hline 23 & 20.7681 & 3.5 & 0.62506 & 2.7 & 0.78 & 0.2410 & 2.2 & 3128 & 34 & 3130 & 68 & 3126 & 35 & 100 & 1.35 \\
\hline 24 & 6.7584 & 3.1 & 0.38517 & 2.1 & 0.66 & 0.1273 & 2.4 & 2080 & 28 & 2100 & 37 & 2060 & 42 & 102 & 0.89 \\
\hline 25 & 6.8308 & 3.2 & 0.38670 & 2.5 & 0.80 & 0.1281 & 1.9 & 2090 & 29 & 2107 & 46 & 2072 & 34 & 102 & 0.44 \\
\hline 26 & 6.7425 & 2.6 & 0.38076 & 2.3 & 0.86 & 0.1284 & 1.3 & 2078 & 24 & 2080 & 40 & 2077 & 24 & 100 & 0.53 \\
\hline 27 & 6.8308 & 2.7 & 0.38503 & 2.1 & 0.79 & 0.1287 & 1.7 & 2090 & 24 & 2100 & 39 & 2080 & 30 & 101 & 0.38 \\
\hline 28 & 16.2819 & 2.6 & 0.57579 & 2.1 & 0.83 & 0.2051 & 1.4 & 2893 & 25 & 2932 & 50 & 2867 & 23 & 102 & 0.08 \\
\hline
\end{tabular}


sediments occur beneath a thick $(210 \mathrm{~m})$ sequence of mafic and ultramafic volcanic rocks that belong to the Antonivka $\left(\mathrm{D}_{2-3}\right)$ and Mykolaivka $\left(\mathrm{D}_{2}\right)$ suites with rare tectonized blocks of felsic rocks (granite and quartz syenite). Sandstone occurs as a lightgrey fine- to medium-grained rock made predominantly of quartz.

Methods. Zircon was separated from ca. $0.5 \mathrm{~kg}$ sample at the M.P. Semenenko Institute of Geochemistry, Mineralogy and Ore Formation of the NAS of Ukraine, Kyiv, using standard methods. Zircons were mounted in resin and polished to half their thickness. Zircons were analyzed for U, Th, and $\mathrm{Pb}$ isotopes by LA-SF-ICP-MS techniques at the Museum für Mineralogie und Geologie (GeoPlasma Lab, Senckenberg Naturhistorische Sammlungen Dresden), using a Thermo-Scientific Element 2 XR sector field ICP-MS coupled to a New Wave UP-193 Excimer Laser System. Each analysis consisted of $15 \mathrm{~s}$ background acquisition followed by $30 \mathrm{~s}$ data collection. Raw data were corrected for background signal, common $\mathrm{Pb}$, laser-induced elemental fractionation, instrumental mass discrimination, and time-dependant elemental fractionation of $\mathrm{Pb} / \mathrm{Th}$ and $\mathrm{Pb} / \mathrm{U}$. Reported uncertainties were propagated by quadratic addition of the external reproducibility obtained from the standard zircon GJ-1 ( $\sim 0.6 \%$ and $0.5-1 \%$ for the ${ }^{207} \mathrm{~Pb} /{ }^{206} \mathrm{~Pb}$ and ${ }^{206} \mathrm{~Pb} /{ }^{238} \mathrm{U}$, respectively) during individual analytical sessions and the within-run precision of each analysis.

Results. Zircons from sandstones of the Mykolaivka Suite are represented by nearly equant to prismatic to elongated prismatic crystals (Fig. 2). Most of the grains are weakly rounded, although some of them have well-preserved crystal facets. Crystals are predominantly transparent to semi-transparent, colourless to pinkish; many of them contain fluid and mineral inclusions. CL imaging reveals com- plex oscillatory zoning typical for igneous zircons. Some of the grains have very thin outer zones / overgrowth having bright cathodoluminescence, in contrast to the dark main parts of the crystals (Fig. 2).

In total, $28 \mathrm{U}-\mathrm{Pb}$ isotope analyses were performed on zircon grains separated (Table). The predominant population (18 grains) has the concordant age of $2075 \pm 9 \mathrm{Ma}(\mathrm{MSWD}=0.64)$. The second population comprises a group of zircon crystals with concordant to nearly concordant ages ranging from 3130 to $2830 \mathrm{Ma}$ (Fig. 3).

Discussion and conclusions. The partly preserved outer shape of zircon crystals and intact thin outer overgrowth indicate the local origin of detrital zircons found in sandstones of the Mykolaivka Suite. This assumption is supported by the results of $\mathrm{U}-\mathrm{Pb}$ isotope dating. The Paleoproterozoic age of $2075 \pm$ $\pm 9 \mathrm{Ma}$ of the prevailing zircon population fits the age of the Khlibodarivka and Anadol granite complexes that widely occur in the East Azov area [18]. The Mesoarchean zircon population could have been derived from numerous Mesoarchean rock assemblages (both igneous and metamorphic) distributed in the area $[7,19]$. Considering large variations of the $\mathrm{Th} / \mathrm{U}$ ratio in this population, it includes both igneous and metamorphic zircons.

The presence of coarse-grained terrigenous sediments (sandstones to gravels) derived from local sources indicates enhanced erosion of the Precambrian basement that might have been caused by differential vertical movements already during Middle Devonian. As evidenced by the age of kimberlites (ca. $384 \mathrm{Ma}$ ), at Givetian time the continental crust has been transacted by deep faults making kimberlite emplacement possible. Apparently, in the Donets basin rifting (and uplift) have started ca. 10 Myr earlier than in other segments of the PDDP, indicating the north-westward rift propagation [14].

\section{REFERENCES}

1. Artemenko, G.V., Shumlyansky, L.V. and Bekker, A.Yu. (2018), Geol. Journ., No. 2(363), Kyiv, UA, pp. $42-57$ [in Russian]. https://doi.org/10.30836/igs.1025-6814.2018.2.133457

2. Bibikova, E.V., Claesson, S., Fedotova, A.A., Artemenko, G.V. and Ilyinsky, L. (2010), Geochem. Intl., Vol. 48, pp. 845861. https://doi.org/10.1134/S0016702910090016

3. Bibikova, E.V., Fedotova, A.A., Claesson, S., Artemenko, G.V. and Anosova, M.O. (2012), Stratigr. Geol. Correl., Vol. 20, pp. 125-138. https://doi.org/10.1134/S0869593812020037

4. Bobrov, O.B., Stepanyuk, L.M., Paranko, I.S., Ponomarenko, O.M., Shumlyanskyy, L.V. and Dhuime, B. (2011), Mineral. Journ., Vol. 33, No. 1, Kyiv, UA, pp. 30-40 [in Ukrainian]. https://doi.org/10.15407/mineraljournal

5. Cawood, P.A., Hawkesworth, C.J. and Dhuime, B. (2012), Geology, Vol. 40, pp. 875-878. https://doi.org/10.1130/G32945.1

6. Chalot-Prat, F., Tikhomirov, P. and Saintot, A. (2007), Journ. Earth Syst. Sci., Vol. 116, pp. 469-495. https://doi.org/ $10.1007 / \mathrm{s} 12040-007-0045-\mathrm{Z}$

7. Claesson, S., Artemenko, G., Bogdanova, S. and Shumlyanskyy, L. (2019), Earth's oldest rocks, 2nd ed., in Martin J. van Kranendonk, Vickie Bennett, Elis Hoffmann (eds), Elsevier, pp. 837-854. 
8. Condie, K.C., Beyer, E., Belousova, E., Griffin, W.L. and O’Reilly, S. (2005), Precam. Res., Vol. 139, pp. 42-100. https://doi.org/10.1016/j.precamres.2005.04.006

9. Fedo, C.M., Sircombe, K.N. and Rainbird, R.H. (2003), Rev. Mineral. Geochem., Vol. 53, pp. 277-303. https://doi. org/10.2113/0530277

10. Francovschi, I., Grădinaru, E., Li, H., Shumlyanskyy, L. and Ciobotaru, V. (2021), Precam. Res., Vol. 355, 106062. https://doi.org/10.1016/j.precamres.2020.106062

11. Gehrels, G. (2014), Ann. Rev. Earth Planet. Sci., Vol. 42, pp. 127-149. https://doi.org/10.1146/annurev-earth-050212124012

12. Gonshakova, V.I., Ruzhitskiy, V.O., Boychuk, M.D., Zaritsky, A.I. and Strekozov, N.E. (1967), Int. Geol. Rev., Vol. 11, pp. 60-73.

13. Kusznir, N.J., Stovba, S.M., Stephenson, R.A. and Poplavskii, K.N. (1996), Tectonophys., Vol. 268, pp. 237-255. https:// doi.org/10.1016/S0040-1951(96), 00230-2

14. Nikishin, A.M., Ziegler, P.A., Stephenson, R.A., Cloetingh, S.A.P.L., Furne, A.V., Fokin, P.A., Ershov, A.V., Bolotov, S.N., Korotaev, M.V., Alekseev, A.S., Gorbachev, V.I., Shipilov, E.V., Lankreijer, A., Bembinova, E.Yu. and Shalimov, I.V. (1996), Tectonophys., Vol. 268, pp. 23-63. https://doi.org/10.1016/S0040-1951(96)00228-4

15. Nikishin, A.M., Romanyuk, T.V., Moskovskii, D.V., Kuznetsov, N.B., Kolesnikova, A.A., Dubenskii, A.S., Sheshukov, V.S. and Lyapunov, S.M. (2020), Moscow Univ. Geol. Bull., Vol. 75, pp. 220-236. https://doi.org/10.3103/ S0145875220030096

16. Paszkowski, M., Budzyń, B., Mazur, S., Sláma, J., Środoń, J., Millar, I.L., Shumlyanskyy, L., Kędzior, A. and Liivamägi, S. (2021), Precam. Res., Vol. 362, 106282. https://doi.org/10.1016/j.precamres.2021.106282

17. Sazonova, L.V., Nosova, A.A., Yutkina, E.V., Kondrashov, I.A. and Shumlyanskyy, L.V. (2019), Petrology, Vol. 27, pp. 633-654. https://doi.org/10.1134/S0869591119060055

18. Shcherbak, N.P., Artemenko, G.V., Lesnaya, I.M., Ponomarenko, A.N. and Shumlyanskyy, L.V. (2008), Geochronology of the early Precambrian of the Ukrainian Shield. Proterozoic, Nauk. dumka, Kyiv, 240 p. [in Russian].

19. Shcherbak, N.P., Artemenko, G.V., Lesnaya, I.M. and Ponomarenko, A.N. (2005), Geochronology of the Early Precambrian of the Ukrainian Shield. Archaean, Nauk. dumka, Kyiv, 244 p. [in Russian].

20. Sheremet, E.M., Kryvdik, S.G., Kozar, N.A., Strekozov, S.N., Vovkotrub, N.V., Setaya, L.D., Nikolayev, I.Yu., Agarkova, N.G., Dubyna, A.V., Gatsenko, V.A. and Lunyov, E.S. (2015), Phanerozoic magmatism of the Eastern Azov area of the Ukrainian Shield and related commercial minerals (petrology, geochemistry, and ore potential), Comprint publ., Kyiv, 318 p. [in Russian].

21. Shumlyanskyy, L.V. and Shumlyanskyy, V.O. (2014), Modern problems of the lithology of sedimentary basins of Ukraine and neighbouring areas, Abstr. vol. of the Int. conf., 6-11 Octob. 2014, Kyiv, UA, p. 109.

22. Shumlyanskyy, L., Hawkesworth, C., Dhuime, B., Billström, K., Claesson, S. and Storey, C. (2015), Precam. Res., Vol. 260, pp. 39-54. https://doi.org/10.1016/j.precamres.2015.01.007

23. Stepanyuk, L.M., Shumlyansky, L.V., Hoffmann, A., Hofmann, M., Kovalik, A. and Bekker, A. (2020), Mineral. Journ. (Ukraine), Vol. 42, No. 2, Kyiv, UA, pp. 45-62 [in Ukrainian]. https://doi.org/10.15407/mineraljournal.42.02.046

24. Stepanyuk, L.M., Shumlyanskyy, L.V., Ponomarenko, O.M., Dovbush, T.I., Vysotsky, O.B. and Dhuime, B. (2010), Geochem. and Ore formation, Vol. 28, Kyiv, UA, pp. 4-10 [in Ukrainian].

25. Wilson, M. and Lyashkevich, Z.M. (1996), Tectonophys., Vol. 268, pp. 65-81. https://doi.org/10.1016/S00401951(96)00234-X

26. Yutkina, E.V., Kononova, V.A., Bogatikov, O.A., Knyazkov, A.P., Kozar, N.A., Ovchinnikova, G.V. and Levsky, L.K. (2004), Petrology, Vol. 12, pp. 134-148.

27. Yutkina, E.V., Nosova, A.A., Sazonova, L.V., Larionova, Yu.O., Kondrashov, I.A., Shumlyanskyy, L.V., Albekov, A.Yu. and Savko, K.A. (2017), Petrology, Vol. 25, pp. 241-271. https://doi.org/10.1134/S0869591117020060

Received 24.04.2021 
Л.В. Шумлянський, д-р геол. наук, пров. наук. співроб.

Інститут геохімії, мінералогії та рудоутворення ім. М.П. Семененка НАН України

03142, м. Київ, Україна, пр-т Акад. Палладіна, 34

E-mail: lshumlyanskyy@yahoo.com; http://orcid.org/0000-0002-6775-4419

М. Гофманн, $\mathrm{PhD}$, зав. лабораторією

Музей природознавства Сенкенберга, Дрезден, Німеччина

E-mail: mandy.hofmann@senckenberg.de; ScopusID: 35334126200

Б.В. Бородиня, начальник загону

Казенне підприємство "Південукргеологія"

49005, м. Дніпро, Україна, вул. Чернишевського, 11

E-mail: boris.priazov@gmail.com

Г.В. Артеменко, д-р геол. наук, проф., зав. відділом

Інститут геохімії, мінералогії та рудоутворення ім. М.П. Семененка НАН України

03142, м. Київ, Україна, пр-т Акад. Палладіна, 34

E-mail: regulgeo@gmail.com; https://orcid.org/0000-0002-4528-6853

\section{МІСЦЕВІ ДЖЕРЕЛА УЛАМКОВОГО МАТЕРІАЛУ КВАРЦИТІВ СЕРЕДНЬОГО ДЕВОНУ ДОНЕЦЬКОГО БАСЕЙНУ: РЕЗУЛЬТАТИ U-Pb LA-ICP-MS ДАТУВАННЯ ЦИРКОНУ}

Наведено результати U-Pb датування цирконів з пісковиків миколаївської світи середнього девону, що відібрано в зоні зчленування Приазовського району Українського щита та Донецького басейну. У свердловині ці осадові породи залягають під потужною (210 м) товщею основних та ультраосновних вулканічних порід, що належать до антонівської $\left(D_{2-3}\right)$ та миколаївської $\left(D_{2}\right)$ світ. Загалом виконано $28 \mathrm{U}-\mathrm{Pb}$ ізотопних аналізів. Головна популяція цирконів (18 кристалів) має конкордантний вік в $2075 \pm 9$ млн рр. (СКЗВ = 0,64). Друга популяція представлена групою кристалів циркону, що мають конкордантний або близький до нього вік у діапазоні 3130-2830 млн рр. Ці результати вказують на місцеве джерело уламкових цирконів, що досліджувалися. Наявність грубозернистих теригенних осадків, отриманих з місцевих джерел, вказує на активну ерозію докембрійського фундаменту, яка могла бути спричиненою диференційованими вертикальними рухами протягом середнього девону. У Донецькому басейні рифтинг і вертикальні рухи розпочалися приблизно на 10 млн рр. раніше, ніж на інших ділянках Прип'ятсько-Дніпровсько-Донецького палеорифту.

Ключові слова: Донецький складчастий басейн, уламковий циркон, U-Pb вік, девон. 